\section{Fruit Temperature and Maturity Affect Development of Blossom End Clearing in Grapefruit}

\author{
E. Echeverria ${ }^{1}$ J.K. Burns, and W.M. Miller \\ University of Florida, Institute of Food and Agricultural Sciences, Citrus \\ Research and Education Center, 700 Experiment Station Road, Lake Alfred, \\ FL 33850-2299
}

\section{Additional index words. Citrus paradisi, juice spot, stylar end breakdown}

\begin{abstract}
The effect of fruit temperature and fruit maturity on the development of blossom end clearing (BEC) in Florida grapefruit (Citrus paradisi Macf. vars. Ruby Red and Marsh) was investigated. Field and storage temperature studies indicated that development of BEC was directly associated with temperature; BEC increased when fruit temperature rose above $21^{\circ} \mathrm{C}$. Cooling fruit prior to packingline operations reduced $\mathrm{BEC}$ significantly. Older fruit were more susceptible to BEC than were younger fruit.
\end{abstract}

Blossom end clearing (BEC) is a postharvest physiological disorder most commonly observed in, but not limited to, late harvested, thin-peeled pink grapefruit (Echeverria and Burns, 1994; McCornack, 1966). Fruit grown in the coastal areas along the Indian River and in adjoining counties of Southeast Florida are more susceptible to development of BEC than fruit grown in the central region of the state. The disorder generally appears as an external, wet, translucent area at the blossom end; however, it can occasionally be observed anywhere on the fruit. The wet area results from juice leaking from the vesicles to the peel (Goell et al., 1988); the appearance is blemished, the fruit develops off flavors, and the area becomes susceptible to invading pathogens. In some crops, up to $90 \%$ of the fruit can be affected (McCornack, 1966). This condition is very similar in appearance to "stylar end breakdown" (SEB) or "juice spot" of 'Tahiti' limes, previously described by Davenport and Campbell (1977a, 1977b) and Davenport et al. (1976).

Factors such as fruit size, rough handling, location, and humidity have a major influence on development of both BEC (McCornack, 1966) and SEB (Davenport and Campbell, 1977a, 1977b; Davenport et al., 1976; Grierson et al., 1971). However, these factors do not always influence the disorders in the same way. For example, small-sized grapefruit are more susceptible to BEC (Echeverria and Burns, 1994), whereas large-sized limes have a higher incidence of SEB.

Florida citrus growers have maintained

Received for publication 4 Dec. 1998. Accepted for publication 22 Apr. 1999. Florida Agricultural Experiment Station Journal Series No. R-6649. Work supported by the Florida Dept. of Citus. The cost of publishing this paper was defrayed in part by the payment of page charges. Under postal regulations, this paper therefore must be hereby marked advertisement solely to indicate this fact.

${ }^{1}$ To whom reprint requests should be sent. E-mail: eje@icon.lal.ufl.edu that BEC in grapefruit is more prevalent in packinghouses in late fruit harvested during and after the flowering period, suggesting that fruit maturity is also an important factor in BEC development. This investigation was designed to determine the effects of temperature and fruit maturity on BEC development of Florida grapefruit.

Expt. 1. Effect of field temperature on development of BEC. About $400 \mathrm{~kg}$ of 'Ruby Red' grapefruit were harvested four times during the day $(0900,1100,1300,1500 \mathrm{HR})$ from a grove in the Indian River district and placed into pallet bins prior to transport to a nearby commercial packinghouse. Fruit were subjected to standard packingline procedures (Grierson et al., 1978) except that they were dropped onto the packingline from a height of $1.25 \mathrm{~m}$ to generate impact forces associated with fruit damage (Miller and Wagner, 1991) and induction of BEC (Echeveria and Burns, 1994). After packing, 20 boxes, each containSolid vertical line represents overnight storage. ing $\approx 35$ fruit, were stored overnight on the packinghouse floor (average $23^{\circ} \mathrm{C}$ ) and visually assessed for the presence of BEC the following morning. A 400-kg sample of fruit collected from the $1500 \mathrm{HR}$ harvest was held overnight under the same conditions, dropped onto the packingline, and processed as above the following morning.

Expt 2. Effect of temperature on the induction of BEC. Preliminary experiments indicated that fruit turgidity also varied substantially during the day. To compensate for turgidity, 'Ruby Red' grapefruit were harvested in Apr. 1994 from a grove in the Indian River area, and brought to the Citrus Research and Education Center (CREC) at Lake Alfred, Fla. Fruit harvested at one time period were dropped after equilibration at several temperatures. Fruit were placed in a storage room and held at 21 ${ }^{\circ} \mathrm{C}$ and $95 \%$ relative humidity (RH) until the next morning, then divided into four groups consisting of 10 boxes containing 35 fruit each. Two groups were held at $37^{\circ} \mathrm{C}$, one at 26 ${ }^{\circ} \mathrm{C}$, and one at $16{ }^{\circ} \mathrm{C}$. Humidity was maintained at $95 \%$. After $24 \mathrm{~h}$, fruit held at 16 and $26^{\circ} \mathrm{C}$, and one group of those held at $37^{\circ} \mathrm{C}$, were dropped as described above to induce BEC, and then passed through the packingline and stored at $21^{\circ} \mathrm{C}, 95 \% \mathrm{RH}$ for two additional days. The remaining group of $37^{\circ} \mathrm{C}$ fruit was transferred to $16^{\circ} \mathrm{C}$ for another $24 \mathrm{~h}$, dropped, and then processed on the packingline. After 2 $d$, fruit were assessed for BEC. Fruit temperature had equilibrated with ambient temperature at the time of BEC induction.

Expt. 3. Effect of fruit maturity on BEC. Indian River 'Marsh' grapefruit was harvested from a grove on seven dates between 29 Jan. and 4 June 1998 as described below. At each date, fruit were collected between 1000 and $1130 \mathrm{HR}$ and divided into six boxes of 50 fruit each. Fruit from three boxes were dropped a distance of $1.25 \mathrm{~m}$ onto a steel plate. All fruit were subsequently stored at $21^{\circ} \mathrm{C}$ at CREC. The following morning the remaining three boxes were similarly dropped. All six boxes of

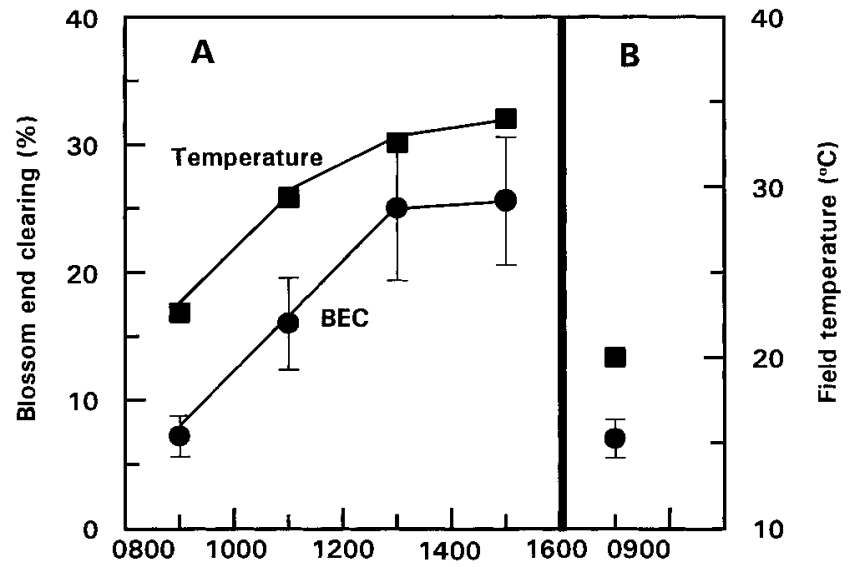

Time of Day

Fig. 1. Expt. 1: (A) Development of BEC ( ) and field temperature ( $\mathbf{\square})$ of Florida grapefruit harvested at several times during the day, transported to the packinghouse, and immediately packed. (B) BEC in fruit harvested at $1500 \mathrm{HR}$, then stored at $23^{\circ} \mathrm{C}$ overnight and packed at $0900 \mathrm{HR}$ on day 2 . Bars represent \pm SE. 


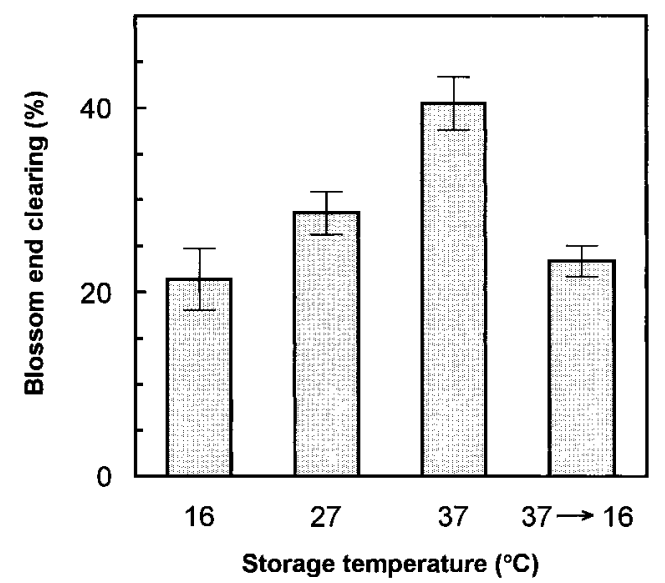

Fig. 2. Expt. 2: Effect of fruit temperature on the development of BEC. Fruit were stored for $24 \mathrm{~h}$ at 16,27 , or $37^{\circ} \mathrm{C}$. One set of fruit previously stored at $37^{\circ} \mathrm{C}$ was cooled to $16^{\circ} \mathrm{C}$. Fruit were then dropped, packed, and transferred to $21^{\circ} \mathrm{C}$. The presence of BEC was assessed after $2 \mathrm{~d}$. Error bars represent \pm SE.

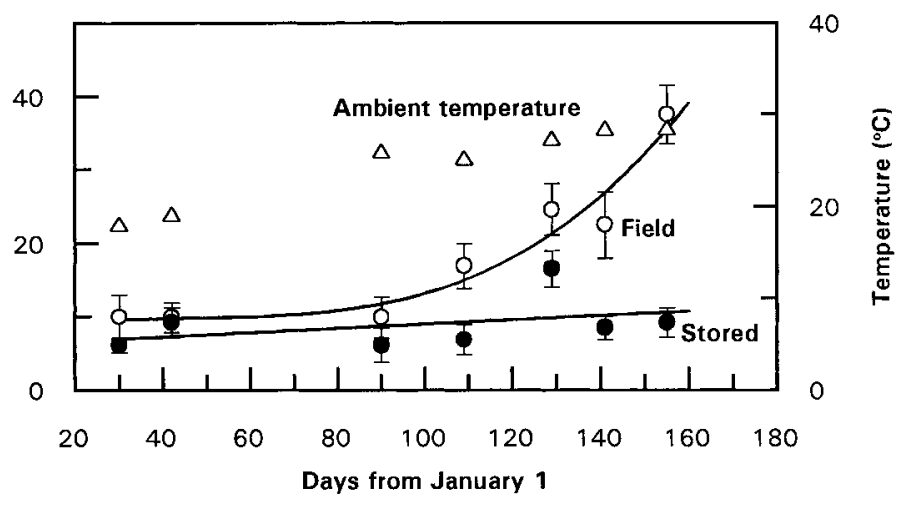

Fig. 3. Expt. 3: Development of BEC in Florida grapefruit throughout the harvesting season. At each harvest time, one set of fruit was dropped (to induce BEC) in the field $(\bigcirc)$ at ambient temperature $(\Delta)$ whereas the remaining sample $(\bullet)$ was stored overnight at $21^{\circ} \mathrm{C}$ prior to dropping. Error bars represent \pm SE. fruit were washed and waxed on the packingline, packed in cardboard cartons, and stored overnight at $21^{\circ} \mathrm{C}$ and $95 \% \mathrm{RH}$. The following day all fruit were visually assessed for BEC.

Increases in field temperature were paralleled by increases in percentage BEC in fruit harvested at different times throughout the day (Fig. 1), with the highest incidence of BEC occurring during the warmest time of the day. However, holding fruit collected at $1500 \mathrm{HR}$ overnight at $21^{\circ} \mathrm{C}$ prior to packingline operations markedly reduced BEC. The percent BEC in fruit held overnight was comparable to that in fruit harvested at $0900 \mathrm{HR}$ the previous day.

In Expt. 2, percent BEC increased with fruit temperature at the time of packing (Fig. 2). However, BEC was low in the sample cooled to $16^{\circ} \mathrm{C}$ after being held at $37^{\circ} \mathrm{C}$ (Fig. $2)$, supporting the data in Fig. 1.

When fruit were dropped immediately after harvest (Expt. 3), BEC increased as harvest was delayed (Fig. 3). However, the effect of maturity was markedly reduced or eliminated when fruit were stored at $21^{\circ} \mathrm{C}$ prior to dropping.

These three experiments demonstrate that high fruit temperatures predispose the fruit to BEC. As the fruit matured, the effect of increased temperatures on BEC became more pronounced. Cooling fruit prior to handling reduced the incidence of $\mathrm{BEC}$ regardless of fruit maturity.

In the field, high impact forces also induce BEC. However, many affected fruit are removed by graders during packing. In the packinghouse, impacted fruit may escape elimination, especially if the impacts occur after grading. A potential strategy to reduce BEC in the packingline is to cool fruit overnight before packing (Echeverria and Burns, 1994).

\section{Literature Cited}

Davenport, T.L. and C.W Campbell. 1977a. Stylarend breakdown: a pulp disorder in 'Tahiti' lime. HortScience 12:246-248.

Davenport, T.L. and C.W. Campbell. 1977b. Stylarend breakdown in 'Tahiti' lime: aggravating effects of field heat and fruit maturity. J. Amer.
Soc. Hort. Sci. 102:484-486.

Davenport, T.L., C.W. Campbell, and P.G. Orth. 1976. Stylar-end breakdown in 'Tahiti' lime: some causes and cures. Proc. Florida State Hort. Soc. 89:245-248.

Echeverria, E. and J.K. Burns. 1994. Handling and storage conditions that affect blossom end clearing development in grapefruit. Proc. Florida State. Hort. Soc. 107:243-245.

Grierson, W., W.M. Miller, and W.F. Wardowski. 1978. Packinghouse machinery for Florida citrus packinghouses. Florida Agr. Expt. Sta. Bul. 620.

Grierson, W., W.F. Wardowski, and G.J. Edwards. 1971. Postharvest rind disorders of 'Persian' limes. Proc. Florida State. Hort. Soc. 84:294-298.

Goell, A., H. Safran, and Y. Erner. 1988. "Juice spot"-A rind disorder in "Star Ruby" red grapefruit in Israel. Proc. Intl. Soc. Citricult., Tel Aviv, Israel p. 1-5.

McCornack, A.A. 1966. Blossom-end clearing of grapefruit. Proc. Florida State Hort. Soc. 79:258264

Miller, W.M. and C.J. Wagner. 1991. Impact studies in Florida citrus packinghouses using an instrumented sphere. Proc. Florida State. Hort. Soc. 104:125-127. 